\title{
REGIONAL FEATURES OF INNOVATIVE DEVELOPMENT AND DIFFERENTIATION OF DIRECTIONS OF INNOVATION POLICY OF RUSSIA
}

\author{
Alexander DUBOVITSKI ${ }^{1 *}$, Elvira KLIMENTOVA², Matvei ROGOV ${ }^{3}$ \\ ${ }^{1}$ Michurinsk state agrarian University, 101, Internatsionalnaya, Michurinsk, Russian Federation, \\ Daa1-408@yandex.ru \\ ${ }^{2}$ Michurinsk state agrarian University, 101, Internatsionalnaya, Michurinsk, Russian Federation, \\ klim1-408@yandex.ru \\ ${ }^{3}$ Michurinsk state agrarian University, 101, Internatsionalnaya, Michurinsk, Russian Federation, \\ rogovmatvej1@gmail.com
}

\begin{abstract}
In our manuscript we have made an attempt to study specific sides of Russian Federation's innovative development, analyze its impact in economy growth and provide main ways of innovative policy realization in different types of regions. The method is based on partial abstraction from the unique properties of each region, thereby uniting them into homogeneous groups using k-means method. Further analysis of the determination of the main factor at the level of country was carried out using decision trees functions with the subsequent collection of $O O B$ errors. Group analysis was carried out using regression analysis. As a result, the authors obtained five types of regions (with a high, above average, average, below average, low level of innovative development), provided an individual characteristic for each group regarding the innovation development and identified prerogative innovative factors that can be considered by the state as a criterion for differentiating state policy and regulation of the development of innovation policy.
\end{abstract}

Keywords: economic growth, innovation, innovation climate, public policy

Original scientific paper

Received: 24.11.2021

Accepted: 10.12 .2021

Available online: 14.12.2021

\section{Introduction}

Despite the ongoing transformation of Russian economy, started in the end of 80th, the sustainable economic growth has not yet been achieved. One of the main problems of the spatial development of the Russian Federation is the high percent of low-productivity and low-tech industries in the structure of Russian regions economy (Averina \& Sirotin (2020).The solution of this problem mostly lies in accelerating of technological modernization of production, above all

* Corresponding author

Note: Paper is presented at the 7th international scientific conference „Innovation as the initiator of development". Extended version of the paper is submitted to the Journal of Process Management and New Technologies. 
in industry, based on modern innovations (Maslennikov, 2017). The ability of innovation to be a driver of economic growth has been proven both by the results of many scientific studies (Benhabib et al., 2017, Mohnen et al., 2018, Astanakulov et al., 2019) and by the experience of many leading countries, including the USA, Japan, China, Germany. Furthermore, there are convincing proofs of the positive innovation impact not only on regional and sectoral dynamics, but also on the high dispersion of labor productivity (Foster et al., 2018, Maslennikov, 2017), as well as on the socio-economic development of territories (Pogodaeva, 2015).

In the modern economy, the key factors of innovation development are investment (Link, 2014, Aničić, 2021), the development of scientific activities (Zmiyak, 2020, Tereshchenko, 2021), entrepreneurship (Acs, 2013, Ejdemo \& Örtqvist, 2021), digital transformation (Karpunina et al., 2021) industry diversity and specialization. (Yang, 2020), small business development (Dubovitski \& Klimentova, 2019, Nikitin et al., 2020), as well as a number of others, which largely determine the possibility of technology diffusion.

However, all these factors affect the economic only in certain institutional conditions (Hinings et al., 2018) and mostly depend on the performance of state and municipal policies (Kokovikhin et al., 2017, Maryasis, 2017, Bloom, 2019). Therefore, the effectiveness of innovative development of different regions and countries are determined by their own innovation climate. According to a World Bank report, Russia is among the top three in terms of regional inequality within the country among the Europe and Central Asia states (Maurizio et al., 2018). Considering the fact that the balanced development of regions is an element of the economy development mechanism (Kok et al., 2021), one of the key factors of the improvement of innovations is the formation of a favorable innovation climate in the regions.

Considerable part of attention is also paid to the study of the issues of innovative development of regions in Russia. Khannanov (2015), for instance, substantiated promising directions for the development of innovative processes and identified the aims that should be achived for sustainable socio-economic growth. The number of studies have demonstrated a significant difference between Russian regions in terms of the level of technical and innovative development, (Polezhaeva, 2015, Karpunina et al. 2020, Tereshchenko, 2021) as well as sectoral characteristics (Dementiev, 2019). The high level of differentiation of Russian regions forms their unique way of the innovation processes course and must be taken into account during the formation of regional policy Pogodaeva (2015).

The variance of Russian regions indicates the need to identify factors that have a decisive influence on the formation of the innovative environment in a particular region. Disclosure of these factors can be regarded as the basis for improving regional innovation policy in order to overcome the socio-economic differentiation of regions. In our study we tried to study the current condition of the innovation climate in the regions and analyze its contribution to the economy of the Russian Federation.

\section{Research data and methodology of region characteristics identification}

The data was obtained from Russian official statistical bureau for the regions of Russia (Report. 2020) and the HSE report on the innovative climate of the constituent entities of the Russian Federation for 2019. We managed to assess various specifications of regional innovative development. The level of innovative development of regions was determined according to 5 aggregated indicators: Socio-economic conditions (SEC), scientific and technical potential (STP), innovation activity (IA), export activity (EA), quality of innovation policy (QIP). Each indicator accepts values from 0 to 1 (where 0 - the worst, 1 - the best) The indicators were normalized and unified for the case of regression analysis. 
The identification of the most characteristics properties was performed by division of the general population of subjects into groups that was carried out using the following instrumentation. To determine the number of groups, hierarchical clustering was performed. The division into groups (multiclass classification) was carried out using the K-means method with the previously found hyperparameter of the number of groups. Due to the Gaussian form of distribution (D'Agostino test $\mathrm{p}<0.05$ ), the data were presented as mean $(\mathrm{m})$ and standard deviation $(\sigma)$. The statistical significance of the study is $\alpha=0.05$.

\section{Innovative activity in Russia}

The indicators based on the official statistics data confirm a high level of inconsistency in the sphere of Russian economy's innovative development (Table 1)

Table 1. Indicators of innovative development of the Russian Federation

\begin{tabular}{lccccccc}
\hline Indicators & $\mathbf{2 0 1 0}$ & $\mathbf{2 0 1 5}$ & $\mathbf{2 0 1 6}$ & $\mathbf{2 0 1 7}$ & $\mathbf{2 0 1 8}$ & $\mathbf{2 0 1 9}$ & $\mathbf{2 0 2 0}$ \\
\hline $\begin{array}{l}\text { The level of organization } \\
\text { innovative activity }\end{array}$ & 9.5 & 9.3 & 8.4 & 8.5 & 12.8 & 9.1 & 10.8 \\
$\begin{array}{l}\text { The volume of shipment of } \\
\text { innovative goods of own } \\
\text { production (million rubles) }\end{array}$ & 1243.7 & 3843.4 & 4364.3 & 4167.0 & 4516.3 & 4863.4 & 5189.0 \\
$\begin{array}{l}\text { The share of innovative products } \\
\text { in the total volume of goods } \\
\text { shipped by organizations (\%) } \\
\begin{array}{l}\text { Costs for innovative activities of } \\
\text { organizations (million rubles) }\end{array}\end{array}$ & 4.9 & 7.9 & 8.4 & 6.7 & 6 & 6.1 & 6.4 \\
\hline
\end{tabular}

Analysis of the data presented in the table 1 shows a steady growth of values responsible for innovation processes, and at the same time, a certain fluctuation in relative indicators. The country achieved an increase in the volume of production and shipment of own-produced innovative goods for the period 2010-2020 by 4.2 times to 5189 billion rubles. The volume of expenditures on innovative activities of organizations for the same period increased by 5.3 times. At first glance, it seems that country got more than decent results over the past decade. However, not everything is so rosy when comparing data expressed in any of the world's reserve currencies. An assessment of the dynamics, for instance, in US dollars, makes it possible to neutralize the depreciation of the ruble that occurred during this period and shows an increase in innovative goods only 1.8 times, and the cost of innovative activities - 2.3 times, which is significantly lower than official statistics.

The dynamics of the relative importance of innovatively active organizations in their total number showed a decrease during 2010-2016, an increase in 2016-2018 and then again, a reduction. The overall growth over this period was only 1.3 percentage points. The share of innovative goods in the total volume of shipped goods, also with a significant level of volatility, increased from $4.9 \%$ to $6.4 \%$ - by 1.5 percentage points.

We should note that the share of domestic spending on research and innovative development in the Russian Federation according to the data for 2019 amounted to 1.04\% of GDP, which is 2-4 times less than, for example, in China (2.24\%), EU countries (2.48\%), USA (3.07\%), Japan (3.2\%), Korea $(4.64 \%),(O E C D, 2021 a)$. Another characteristic feature of Russian innovation activity is the low share of commercial enterprises in financing R\&®D costs in comparison with economically developed countries - less than $30 \%$, while the share of government spending is about $70 \%$ (OECD, 2021b). 
The structure of the economy that has developed in the country within the framework of the international division of labor is mostly focused on the export of raw materials and goods with a low share of added value (Neganova \& Dudnik, 2019), which leads to a low domestic demand for innovations and low interest of owners and management of enterprises in implementation of innovations. In general, it should be stated that the solution of the the fastest technological modernization problems is still a matter of the future, and the state will have to make serious efforts, especially in the direction of improving the innovation climate.

\section{Circumstances of development of Russian regions}

Considering the above-mentioned importance of regional innovation features in the effectiveness of innovations implementation, we have decided to group the regions of the Russian Federation according to the indicators of innovative development. In fig. 1 and tab. 2 shows a form of distribution of 5 studied indicators.

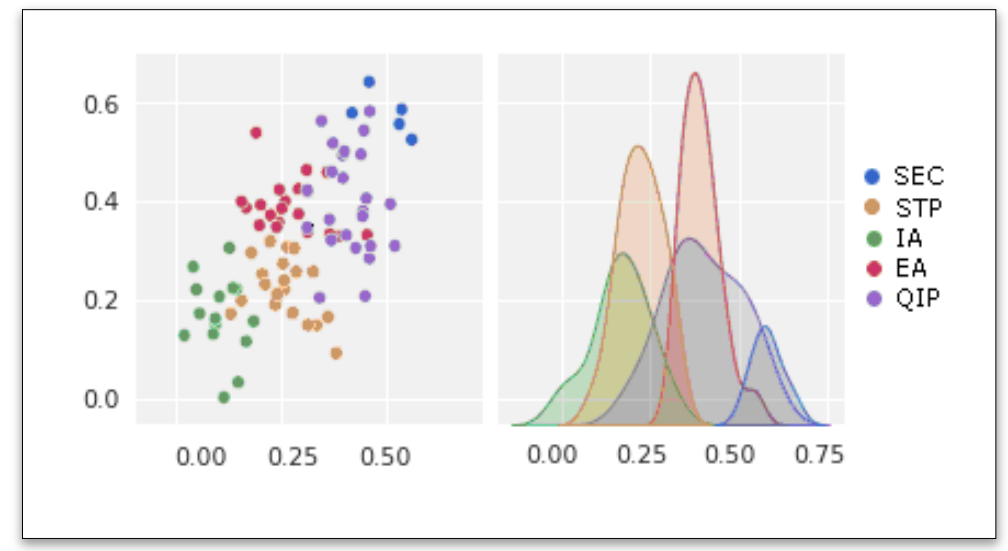

Figure 1. Characteristics of Russian regions innovative development groups

Table 2. Comparative characteristics of Russian regions innovative development

\begin{tabular}{ccccccc}
\hline Group & Amount & \multicolumn{5}{c}{ Indicators of the innovation climate } \\
\hline & & SEC & STP & IA & EA & QIP \\
\hline I & 5 & $0.5 \pm 0.05$ & $0.55 \pm 0.04$ & $0.51 \pm 0.03$ & $0.5 \pm 0.05$ & $0.58 \pm 0.03$ \\
\hline II & 24 & $0.41 \pm 0.03$ & $0.42 \pm 0.05$ & $0.27 \pm 0.06$ & $0.41 \pm 0.05$ & $0.4 \pm 0.09$ \\
\hline III & 20 & $0.37 \pm 0.03$ & $0.38 \pm 0.03$ & $0.36 \pm 0.08$ & $0.27 \pm 0.06$ & $0.39 \pm 0.04$ \\
\hline IV & 21 & $0.36 \pm 0.05$ & $0.35 \pm 0.04$ & $0.21 \pm 0.04$ & $0.26 \pm 0.05$ & $0.22 \pm 0.05$ \\
\hline V & 15 & $0.32 \pm 0.04$ & $0.28 \pm 0.06$ & $0.12 \pm 0.05$ & $0.10 \pm 0.04$ & $0.17 \pm 0.06$ \\
\hline \multicolumn{7}{c}{ Source: authors' calculations }
\end{tabular}

Inclusion of each regions in its own group, a typification was built that summarizes and classifies the regions by groups of indicators. The first group (high level) include 5 regions, the average level of all indicators is 0.53 points. The main feature of this group is complete dominance in all of the 5 indicators. Current group includes capitals and regions, which include large urban agglomerations. The regions of this group are located mainly in the European part of the country except Tomsk region. The leader in the group is St. Petersburg, with an average of 0.54 in 5 indicators. Figure $1 \mathrm{w}$ shows the Top 5 of the best constituent entities of the Russian Federation in terms of investment development. 


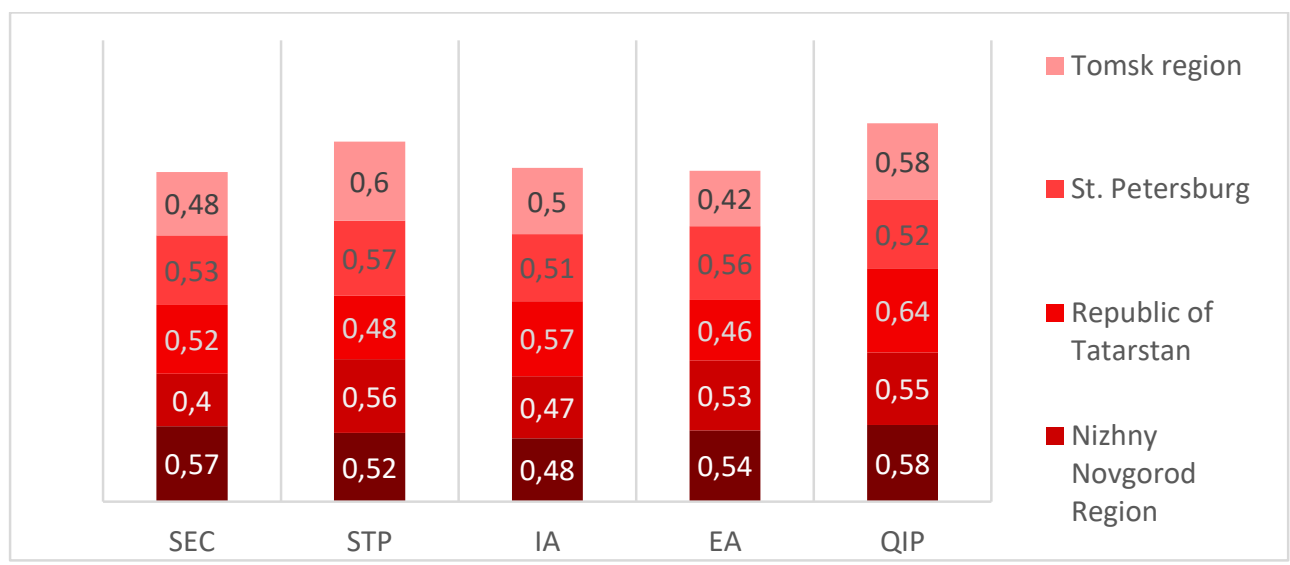

Figure 2. Indicators of innovative development of Russian regions in group I (high level) Source: authors' calculations

In the II (above average) group contain regions mostly located next to the capital regions and so-called "old industrial" territories. Average scores for 5 indicators of each region are $0.46,0.45$, 0.44 points respectively. This group is characterized by rather low scores on the basis of innovative activity - only 0.27 . The values of other indicators lag behind the leading group by an average of 0.14 points. Old industrial territories mostly characterized by high level of specialization and the main problem of such territories is the orientation on the old technologies and equipment (Tödtling \& Trippl, 2005).

Group III (average) is characterized by a low level of export policy, as well as a growing lag in all classes relative to groups I and II. The leading position in the group belongs to the Belgorod region, which has 0.4 points on average for 5 indicators. It is followed by the Voronezh and Lipetsk regions, as well as the Khabarovsk Territory. The gap from the leading group is on average 0.17 points. As can be seen on the map, the main concentration of Group III units falls on the Central District of the Russian Federation. Regions of this group are characterized by lower number of research institutes (including universities) and by lower quality of research and innovations products. Those regions differ from others by the domination of small and mediumsized businesses, the problem of support organization for innovation policy (knowledge transfer) and the lack of budgetary expenditures on science and innovation.

The IV (below average) group shows a sharp decrease in all indicators relative to the higher groups, the average of group is 0.28 . The average deviation from the leader group is 0.28 for all indicators. According to the study, the population is concentrated in the northern and far eastern parts of Russia. The leading place belongs to the Arkhangelsk region, with an average of 0.32 . The last place is Khanty-Mansisky Autonomous Region, only 0.22 points on average. The gap from the leader is 0.24 points per 1 . A characteristic feature, in addition to all of the above, is the extremely low indicators of innovation activity and the quality of innovation policy -0.2 and 0.22 , respectively, compared with the leader group - 0.5 and 0.57 . Regions of this group are characterized by the same problems as the group III but in this case, they are deeper and more complex. Those problems are even more expressed on the background of weak development of production and low level of socio-economic conditions.

The V (low) group is characterized by an extremely low level in three indicators, namely: innovation activity, export level, quality of innovation policy. The lowest values are taken by the indicator of export activity, which is only 0.1 , which is on 0.4 points lower than in the leader's group. The cumulative group average is 0.2. The worst region is Chukotka, with a score of 0.11. The average lag behind the leader's group is 0.32 points. The regions of this group are 
concentrated mainly in the North Caucasian Federal District, as well as in the Far East. The main direction of specialization of this group are mostly traditional, that has been forming over long historical period. Most regions are characterized with low level of living and high rate of unemployment. In those regions the connections between the special knowledge producers such as universities and commercial organizations are not developed enough.

After presenting a brief description for each group, it is important find the factors that have the greatest impact on inclusion each of the region in particular group. We should answer following question: Which of the indicators is the most important from the point of assigning each region to one of the groups. To answer this question, a random forest machine learning model was built. The essence of the algorithm is to construct an ensemble of decision functions voting for assigning each of the region to one of the groups. The final decision is made by finding the average for these votes with the subsequent translation of this estimate into the probabilistic space. However, we will not be interested in the algorithm itself, but in its consequence. To assess the quality of the model, the so-called loss function is used. We can remove each of the indicator during the model building and look at the loss function. If the indicator makes a significant contribution to the model, the loss function will decrease greatly, thus carrying out some kind of cross-validation for the indicators, we will find out the importance of each studied indicator in group. The quantitative assessment is shown in Fig. 3.

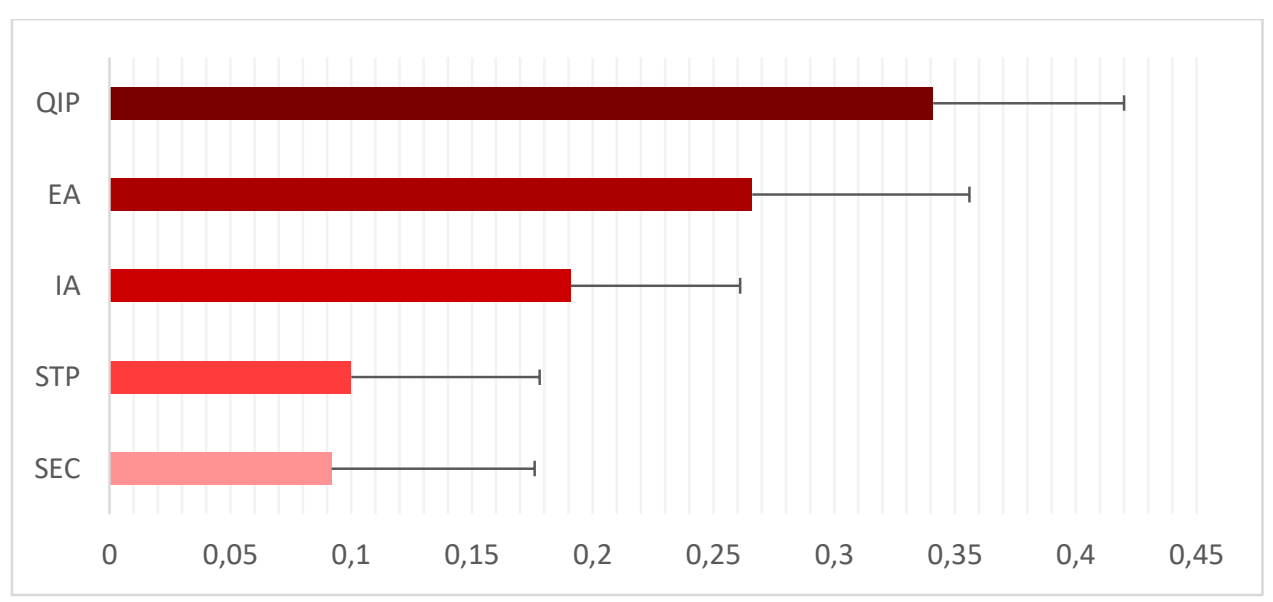

Figure 3. Quantitative assessment of the significance of the factors of innovative development Source: authors' calculations

It also remains very important to determine the significance of each of the indicators directly within the group. For this case we used regression-correlation analysis to find the most important factor in the group. Earlier, within each group, all the regions were sorted according to their rank. Then a hypothesis was put forward about the significant influence of one or group of studied indicators on the rank of this region. The criterion for accepting / rejecting the model was the fulfillment of the theorem of the Markov-Gauss for linear regression. The criterion for accepting / rejecting the hypothesis was the fulfillment of the following points:

1. There is a significant correlation between the indicator and the place of the subjects in the ranking.

2. A large proportion of normalized variance can be described by a regression model $\left(\mathrm{R}^{\wedge}\right.$

2)

3. The regression coefficient is statistically significant in the model $(\mathrm{p}<0.05)$

4. Model is statistically significant (F-test)

5. The standard error of the model does not exceed $95 \%$ confidence interval

6. Presence of dispersion homoscedasticity (Goldfeld-Quandt test) 
Regional Features of Innovative Development and Differentiation of Directions of Innovation Policy of Russia

7. The errors have normal distributed form (Shapiro-Wilk test).

As a result, we managed to identify the most important indicator of innovation climate in each group (Table 3).

Table 3. Results of regression-correlation analysis of the importance of innovative development factors within groups of Russian regions

\begin{tabular}{|c|c|c|c|c|c|c|}
\hline Indicator & $\mathbf{R}^{2}$ & $\mathbf{R}$ & Std. & P-value & Coefficient & $\mathbf{n}$ \\
\hline \multicolumn{7}{|c|}{ Group I } \\
\hline SEC & 0.9 & 0.96 & 0.57 & 0.002 & -25.12 & 6 \\
\hline STP & 0 & 0.3 & 2 & 0.56 & 12.57 & 6 \\
\hline IA & 0.28 & 0.65 & 1.59 & 0.16 & -23.27 & 6 \\
\hline EA & 0 & 0.35 & 1.96 & 0.5 & -11.21 & 6 \\
\hline QIP & 0.12 & 0.54 & 1.76 & 0.27 & -24.59 & 6 \\
\hline \multicolumn{7}{|c|}{ Group II } \\
\hline SEC & 0 & 0.23 & 8.74 & 0.32 & 20.5 & 21 \\
\hline STP & 0.36 & 0.63 & 7 & 0.0024 & -105.25 & 21 \\
\hline IA & 0.27 & 0.56 & 7.45 & 0.01 & -76.56 & 21 \\
\hline EA & 0 & 0.01 & 8.94 & 0.7 & 12.08 & 21 \\
\hline QIP & 0.27 & 0.56 & 7.46 & 0.01 & -80.3 & 21 \\
\hline \multicolumn{7}{|c|}{ Group III } \\
\hline SEC & 0.07 & 0.07 & 5.51 & 0.18 & -43.68 & 15 \\
\hline STP & 0.16 & 0.16 & 5.23 & 0.08 & -28.33 & 15 \\
\hline IA & 0.05 & 0.05 & 5.57 & 0.22 & -29.75 & 15 \\
\hline EA & 0.02 & 0.02 & 5.65 & 0.28 & -35.4 & 15 \\
\hline QIP & 0.5 & 0.5 & 4.02 & 0.001 & -51.89 & 15 \\
\hline \multicolumn{7}{|c|}{ Group VI } \\
\hline SEC & 0.26 & 0.54 & 10.7 & 0.01 & -177.28 & 20 \\
\hline STP & 0 & 0.19 & 12.52 & 0.43 & 46.33 & 20 \\
\hline IA & 0.47 & 0.71 & 9 & 0.0001 & -87.25 & 20 \\
\hline EA & 0.18 & 0.48 & 11.21 & 0.03 & -75.29 & 20 \\
\hline QIP & 0.16 & 0.45 & 11.37 & 0.05 & -104.82 & 20 \\
\hline \multicolumn{7}{|c|}{ Group V } \\
\hline SEC & 0.19 & 0.48 & 12.51 & 0.02 & -168.3 & 24 \\
\hline STP & 0.34 & 0.61 & 11.27 & 0.02 & -121.37 & 24 \\
\hline IA & 0.46 & 0.69 & 10.26 & 0. & -133.22 & 24 \\
\hline EA & 0 & 0.02 & 14.22 & 0.92 & -5.03 & 24 \\
\hline QIP & 0.56 & 0.76 & 9.24 & 0.001 & -99.38 & 24 \\
\hline
\end{tabular}

Thus, the following inferences can be made. In the first group, the most significant factor is socio-economic conditions (SEC). SEC indicator combines the factors of the efficiency of the regional economy (labor productivity, renewal of fixed assets), the availability of human resources for innovation development and the potential of digitalization. In the second group scientific and technical potential (STP), reflecting the factors of the state of resources (financial and human) and the effectiveness of research and development. In the third - the quality of 
innovation policy (QIP), which reflects the factors for assessing the regulatory framework of innovation policy, organizational support of innovation policy, the amount of budgetary expenditures on science and innovation. In the fourth - innovation activity (IA), which reflects factors of innovative activity of organizations in the field of technological and non-technological innovations, factors of the development of small innovative business and indicators of the effectiveness of innovative activities, based on an assessment of the volume of innovative products and its structure in terms of the level of novelty. In the fifth group, as well as in the third, the quality of innovation policy (QIP) is the most important. The group of indicators of the export activity of the regions doesn't significantly impact on the final assessment indicators for any of the studied groups.

We matched the GRP of Russian regions with the studied groups to prove that the classification can be applied for characterization of region using different indicators. We used the indicators of the absolute value of the GRP of the constituent entities of the Russian Federation for 2019 and the average annual growth rate of the GRP for the period 2017-2019 were used (Table 4). The group mean was taken as the comparison criterion, the hypothesis of the difference between the groups was proven using the Student's t-test for unrelated groups.

Table 4. Extrapolation of the classification by groups to the indicators and dynamics of the GRP of the regions of Russia

\begin{tabular}{|c|c|c|c|c|c|c|}
\hline \multirow[t]{2}{*}{ Indicator } & \multicolumn{5}{|c|}{ Groups } & \multirow{2}{*}{$\begin{array}{l}\text { Mean } \\
\text { value }\end{array}$} \\
\hline & I & II & III & IV & $\mathrm{V}$ & \\
\hline $\begin{array}{l}\text { Average value of innovative } \\
\text { development for } 5 \text { indicators }\end{array}$ & 0.53 & 0.38 & 0.35 & 0.28 & 0.20 & 0.35 \\
\hline Average GRP (billion rubles) & 4298.6 & 1540.4 & 793.7 & 669.9 & 603.0 & 1581.12 \\
\hline $\begin{array}{l}\text { Average annual GRP growth rate } \\
\text { during } 2017-2019(\%)\end{array}$ & 175.8 & 113.7 & 110.5 & 106.3 & 109.5 & 123.16 \\
\hline
\end{tabular}

The calculations show a clear dependence of the size and growth rate of GRP from the indicators of innovative development of regions. The leader in terms of GDP is Group I - 5967 billion rubles average. Further, as the indicators of innovativeness of the regions decrease, the average value of GRP by groups of regions and the average rate of economic growth also decrease. In second place is Group II, where the average GRP is 1,656 billion rubles, and the average growth rate in nominal terms is $13.7 \%$. Third place - III group with 793.7 billion. Fourth place - IV group - 669.9 billion rubles. Fifth place - Group V - 603 billion rubles. Looking at the rating, we can say that the highest average indicator of innovative development corresponds to a higher GDP, expressed in monetary terms, and its growth rate. Comparisons were made between all groups, statistically significant differences were recorded between all groups $(p$ $<0.05)$, except for groups IV and V. ( $p=0.093)$. In this regard, it can be concluded that there is a direct relationship between the indicators of innovation and the level of GDP.

\section{Preferred directions for the implementation of innovation policy in various types of regions}

Innovation policy is related to the area of socio-economic policy that determines the ways of innovation development in the region. As Edquist (2019) notes, it is a policy that brings together all social actions that influence or may influence innovation processes. And the issues of policy transformation are always raised in connection with the low efficiency of the innovation system. Many researchers note that innovation policy is subject to constant adjustment depending on the 
political agenda and understanding of innovation processes (Diercks et al., 2019). The practice of forming an innovation policy presupposes the presence of goals, directions, and tools for their implementation by public authorities in the field of R\&®D and the implementation of the results obtained.

At the same time, the toolkit is understood as a combination of specific instruments of government regulation, the explicit or implicit interaction of which affects the intensity of innovation (Borrás \& Edquist, 2013). Moreover, as the authors note, the general direction of the development of innovation policy and tools for its implementation within the existing political paradigm is laid on the basis of identifying urgent problems in the innovation system that form market and systemic failures, institutional blockages (Tödtling \& Trippl, 2005, Wieczorek \& Hekkert, 2012). In fact additional influence is required from the government side on the innovation system, in the direction of improvement, to the point that it is impossible to ensure self-regulation of the market and the actions of private entities.

The main goals of modern economic policy in Russia are to ensure economic growth, increase productivity and competitiveness. Based on the importance of considering the regional difference in innovation policy (Morgan, 1997, Cooke et al., 1997, Tödtling \& Trippl, 2005), and relying on the results of the typification of innovative development of regions, it is possible to formulate preferential directions for the implementation of innovation policy in different types of regions.

In this case, for the first group of regions with a high level of innovative development, we should advice to use tools to keep developing the existing advantages of scientific and technical potential to achieve synergy and expand participation in international cooperation of the global knowledge economy. It is relevant to encourage interaction between research organizations and the industry of these regions and the promotion of knowledge to adjacent regions.

For the II group of regions, characterized by a lower level of scientific research performance and the prevalence of old industries, the main task is to update the regional economy. In parallel with the development of traditional industry in these regions, it is necessary to support the development of new and related industries with a high potential for innovation, including innovative small business. This requires the stimulation of research projects in new topical areas.

In the III group of regions with a feature of a low level of research organizations, the dominance of small and medium-sized businesses and the problems of organizational support for innovation policy, it is necessary to increase the scientific and technical potential and modernize the regional economy. In these regions, the development of branches of national research universities, the support of innovative opportunities for small businesses, the attraction of large innovative firms and the creation of new industries and enterprises can have positive effects.

Weak industrial development and low socio-economic development of the territories of the IV group determine the criticality of the level of innovative activity of organizations in the field of technological and non-technological innovations. In the regions of this group, it is necessary to ensure the development of transport infrastructure, to ensure the strengthening of the economy on the basis of a "catch-up" strategy for the development of innovative opportunities for private business. Just as in group III, it is required to attract scientific knowledge and large business, not only to increase the innovativeness of the economy, but also to increase the development of territories.

In the $\mathrm{V}$ group of regions, the directions of innovation policy should be implemented, aimed at stimulating the development of existing and the creation of new enterprises using labor mobility schemes. It is necessary to develop business cooperation with scientific and technical 
clusters outside the region in order to initially attract knowledge and technology. Financial support of business demand for innovation will be essential.

For all five groups, it should be emphasized, the important role of the cooperation development between producers and consumers of innovations, in the promotion of new technologies and industries at the regional, national and international levels. The prerequisites for innovative development differ significantly from group to group. The fullest consideration of the socio-economic and innovative features of the regions will allow us to conduct a more accurate adjustment of the directions of innovation policy and ensure the fullest use of the existing potential.

\section{Conclusion}

The grouping of Russian regions according to the indicators of innovative development made it possible to distinguish five types of regions according to the level of the innovative climate (high, above average, medium, below average, low) and to systematize the regions by these groups. As a result of the conducted regression-correlation analysis, we were able to identify the most significant factors in each of the groups, the main of which are socio-economic conditions and the quality of innovation policy in the regions. These factors can be considered by the state as a criterion for differentiating state policy and regulating the development of innovation policy.

\section{References}

Abdrakhmanova, G., Artemov, S., Bakhtin P. et al. (2020). Russian Regional Innovation Scoreboard, Issue 6. Edited by L. Gokhberg (ed.). National Research University Higher School of Economics, Moscow: HSE. https://issek.hse.ru/mirror/pubs/share/315338500 (26.09.2021).

Acs, ZJ, Audretsch, DB \& Lehmann, EE (2013). The knowledge spillover theory of entrepreneurship. Small Business Economics, 41(4), 757-774.

Aničić. D., Nestorović, O. \& Andjelković, D. (2021). Investment environment and development policy of enterprises in Serbia. Journal of process management and new technologies, 9(1), 17. https://doi.org/10.5937/jouproman9-30925.

Astanakulov, O. T., Kuchkovskaya, N. V., Bataeva, P. S., Khokhlova, N. I., \& Calesci, M. (2019). Providing Innovative Processes in the Economic Development of the Russian Regions. Space and Culture, India, 7(2), 125-142. https://doi.org/10.20896/saci.v7i2.456.

Averina, L. M. \& Sirotin, D. V. (2020). Assessment of Spatial Effects from Innovation Activities in the Industrialized Russian Regions. Economy of region, 16(1), 268-282. http://dx.doi.org/10.17059/2020-1-20.

Benhabib, J., Perla, J. \& Tonetti, C. (2021). Reconciling Models of Diffusion and Innovation: A Theory of the Productivity Distribution and Technology Frontier. Econometrica, 89, 22612301. https://doi.org/10.3982/ECTA15020.

Bloom, N., Reenen, Van H. \& Williams, J. (2019). Policy of innovation support: a set of tools. Questions of Economics, 10, 5-31. https://doi.org/10.32609/0042-8736-2019-10-5-31.

Borrás, S., \& Edquist, C. (2013). The choice of innovation policy instruments. Technological $\begin{array}{llll}\text { Forecasting } \text { and } & \text { Social }\end{array}$ https://doi.org/10.1016/j.techfore.2013.03.002. 
Cooke, P., Uranga, M. G., \& Etxebarria, G. (1997). Regional innovation systems: Institutional and organisational dimensions. Research Policy, 26(4-5), 475-491. https://doi.org/10.1016/s0048-7333(97)00025-5.

Dementiev, V. E. (2019). Productivity Paradox in Regional Dimension. Economy of Region, 15(1), 43-56. http://dx.doi.org/10.17059/2019-1-4.

Diercks, G., Larsen, H., \& Steward, F. (2019). Transformative innovation policy: Addressing variety in an emerging policy paradigm. Research Policy, 48(4), 880-894. https://doi.org/10.1016/j.respol.2018.10.028.

Dubovitski, A. A. \& Klimentova E. A. (2019). Key guidelines for the economic development of small agribusiness. Economics of agricultural and processing enterprises, 12, 89-94. https://doi.org/10.31442/0235-2494-2019-0-12-89-94.

Edquist, C. (2019). Towards a holistic innovation policy: Can the swedish national innovation council (NIC) be a role model? Research Policy, 48(4), 869-879.

Ejdemo, T., \& Örtqvist, D. (2021). Exploring a leading and lagging regions dichotomy: Does entrepreneurship and diversity explain it? Journal of Innovation and Entrepreneurship, 10(1). https://doi.org/10.1186/s13731-021-00146-8.

Foster, L., Grim, C., Haltiwanger, J. C. \& Wolf, Z (2018). Innovation, Productivity Dispersion, and Productivity Growth, NBER Working Paper 24420. https://doi.org/10.3386/W24420.

Hinings, B., Gegenhuber, T., \& Greenwood, R. (2018). Digital innovation and transformation: An institutional perspective. Information and Organization, 28(1), 52-61. https://doi.org/10.1016/j.infoandorg.2018.02.004.

Karpunina, E.K. et al. (2020). Dialectics of Sustainable Development of Digital Economy Ecosystem. Lecture Notes in Networks and Systems, 129 LNNS, 486-496. https://doi.org/10.1007/978-3-030-47945-9_54.

Karpunina, E.K. et al. (2021). State policy of transition to Society 5.0: identification and assessment of digitalisation risks. Int. J. Public Law and Policy, 7(4), 334-350.

Khannanov, K. M. (2015). Promising directions for the development of innovative processes in the regions: problems and tasks. Regional economics: theory and practice, 39(414), 56-68.

Kok, K. P. W., Loeber, A. M. C., \& Grin, J. (2021). Politics of complexity: Conceptualizing agency, power and powering in the transitional dynamics of complex adaptive systems. Research Policy, 50(3), 104183. https://doi.org/10.1016/j.respol.2020.104183.

Kokovikhin, A. Yu., Ogorodnikova, E. S., Williams, D. \& Plakhin, A. Ye. (2017). Institutional Factors in the Evaluation by the Entrepreneur of Municipality Investment Climate. Economy of Region, 13(1), 80-92. http://dx.doi.org/10.17059/2017-1-8.

Link, A. N., Ruhm C. J. \& Siegel, D. S. (2014). Private Equity and the Innovation Strategies of Entrepreneurial Firms: Empirical Evidence from the Small Business Innovation Research Program, Managerial and Decision Economics, 35(2), 103-113. https://doi.org/10.1002/MDE.2648.

Maryasis, D. (2017). Possibilities of transformation of the system of state support for the development of innovations. The experience of Israel. Economic policy, 12 (5), 80-103. http://dx.doi.org/10.18288/1994-5124-2017-5-05.

Maslennikov, M. I. (2017). The Technological Innovations and their Impact on the Economy. Economy of region, 13(4), 1221-1235. http://dx.doi.org/10.17059/2017-4-20. 
Maurizio, B., Dávalos, M. E., Peragine, V. \& Sundaram, R. (2018). Toward a New Social Contract: Taking On Distributional Tensions in Europe and Central Asia. Overview booklet. World Bank, Washington. https://openknowledge.worldbank.org/bitstream/handle/10986/30393/211353ovRU.pdf? sequence $=11(10.11 .2021)$

Mohnen, P., Polder, M. \& van Leeuwen, G. (2018). ICT, RED and Organizational Innovation: Exploring Complementarities in Investment and Production, NBER Working Paper 25044. https://doi.org/10.3386/w25044.

Morgan, K. (1997). The learning region: Institutions, innovation and regional renewal. Regional Studies, 31(5), 491-503. http://dx.doi.org/10.1080/00343409750132289.

Neganova, V. P. \& Dudnik, A. V. (2019). Openness to Innovations of the Regional Agro-Industry as a Subjective Factor of Innovative Activity. Economy of region, 15(3), 880-892. http://dx.doi.org/10.17059/2019-3-19.

Nikitin, A., Klimentova, E., Dubovitski, A. (2020). Impact of small business innovation activity on regional economic growth in Russia. Revista Inclusiones, 7(SI) 309-321.

OECD (2021a). Gross domestic spending on RED (indicator). https://data.oecd.org/rd/grossdomestic-spending-on-r-d.htm (10.11.2021).

OECD (2021b). Main Science and Technology Indicators, Volume 2021 Issue 1. OECD Publishing, Paris. https://doi.org/10.1787/eea67efc-en.

Pogodaeva, T. V. \& Zhaparova, D. V. (2015). The impact of innovations on the socio-economic development of territories: problems of regions of intensive nature management. Regional economy: theory and practice, 7(382), 16-27.

Polezhaeva, A. Yu. (2015). Analysis of conditions for the development of innovations: typology of regions. Regional economy: theory and practice, 45(420), 50-62.

Report "Socio-economic situation of Russia" (2020). Federal State Statistics Service, Moscow. https://rosstat.gov.ru/compendium/document/50801.

Tereshchenko, D. S. \& Shcherbakov, V. S. (2021). The Impact of Scientific Activity of Universities on Economic and Innovative Development. Economy of Region, 17(1), 223-234. https://doi.org/10.17059/ekon.reg.2021-1-3.

Tödtling, F., \& Trippl, M. (2005). One size fits all?: Towards a differentiated regional innovation policy approach. Research Policy, 34(8), 1203-1219.

Wieczorek, A.J. \& Hekkert M.P. (2012). Systemic instruments for systemic innovation problems: a framework for policy makers and innovation scholars. Sci. Public Policy, 39, 74-87. http://dx.doi.org/10.1093/scipol/scr008.

Yang, N., Liu, Q., \& Qi, Y. (2020). Does (un)-related variety promote regional innovation in China? industry versus services sector. Chinese Management Studies, 14(3), 769-788.

Zmiyak, S. S., Ugnich, E. A., \& Taranov, P. M. (2020). Development of a regional innovation ecosystem: The role of a pillar university. In book: Growth Poles of the Global Economy: Emergence, Changes and Future Perspectives, 567-576. https://doi.org/10.1007/978-3-030-15160-7_47.

(C) 2021 by the authors. Submitted for possible open access publication under the terms and (c) (i) conditions of the Creative Commons Attribution (CC BY) license (http://creativecommons.org/licenses/by/4.0/). 